\title{
EFEKTIFITAS PENGGUNAAN MEDIA GAMBAR SERI DALAM PEMBELAJARAN KETERAMPILAN MENULIS CERITA SISWA KELAS III SDN 10 PARENRING KECAMATAN TANETE RIAJA KABUPATEN BARRU
}

\author{
Sitti Aida Azis, Tjodding. \\ Pendidikan Guru Sekolah Dasar, Fakultas Keguruan dan Ilmu Pendidikan \\ Universitas Muhammadiyah Makassar \\ Iqramsyar34@gmail.com
}

\begin{abstract}
ABSTRAK
Penelitian ini adalah penelitian eksperimen yang bertujuan untuk mengetahui apakah penerapan media gambar seri efektif diterapkan dalam pembelajaran menulis cerita pada siswa Kelas III SDN 10 Parenring Kecamatan Tanete Riaja Kabupaten Barru. Populasi dalam penelitian ini adalah seluruh siswa Kelas III SDN 10 Parenring Kecamatan Tanete Riaja Kabupaten Barru.Tahun Pelajaran 2016/2017 yang terdiri dari satu kelas. l. Pengumpulan data dilakukan dengan menggunakan instrumen berupa tes hasil belajar menulis cerita siswa. Data yang diperoleh selanjutnya dianalisis dengan menggunakan tekhnik analisis statistika, yakni statistika deskriptif. Dari hasil analisis statistika deskriptif diperoleh nilai rata-rata sebelum perlakuan (pretest) $=58,73$ dengan standar deviasi 13,970 berada dalam kategori sangat rendah dan nilai rata-rata setelah perlakuan (posttest) $=76,13$ dengan standar deviasi 7,825 berada dalam kategori tinggi, maka diperoleh $t_{0,05}=2,045$. Setelah diperoleh $t_{\text {hitung }}=7,76$ dan $\mathrm{t}_{\text {tabel }}=2,045$, maka $\mathrm{t}_{\text {hitung }} \geq \mathrm{t}_{\text {tabel. }}$. Sehingga dapat disimpulkan bahwa $\mathrm{H}_{0}$ ditolak dan $\mathrm{H}_{1}$ diterima. Berdasarkan uraian diatas maka dapat disimpulkan bahwa media gambar seri efektif diterapkan dalam pembelajaran menulis cerita pada siswa kelas III SDN 10 Parenring Kecamatan Tanete Riaja Kabupaten Barru.
\end{abstract}

Kata kunci: media gambar seri; menulis cerita 


\section{PENDAHULUAN}

Dalam pelajaran Bahasa Indonesia di SD, guru mengupayakan membentuk kompetensi mendengarkan atau menyimak, berbicara, membaca dan menulis sebagai 4 aspek bahasa yang saling berkaitan.Dalam praktek pembelajaran, guru mengutamakan pada salah satu aspek saja, sedangkan ketiga aspek yang lainnya sebagai pembelajaran terpadu. Menulis merupakan sebuah proses kreatif menuangkan gagasan dalam bentuk bahasa tulis. Hasil dari proses kreatif ini biasa disebut dengan istilah karangan atau tulisa.

Kemampuan menulis di SD tidak diperoleh dari hasil begitu saja akan tetapi memerlukan tahap - tahap pembelajaran yang membutuhkan waktu yang tidak sedikit tetapi membutuhkan proses yang cukup lama. Proses yang dilakukan oleh siswa dalam melatih menulis dipermulaan yang secara formal dilakukan melalui pembelajararan bahasa Indonesia yang dimulai sejak SD.

Salah satu upaya yang bisa dilakukan oleh seorang guru dalam proses pembelajaran agar siswa lebih aktif dan kreatif dalam pembelajaran bahasa Indonesia khususnya pembelajaran keterampilan menulis cerita di kelas III yaitu dengan menggunakan media gambar seri dalam pembelajaran bahasa Indonesia.

Media pembelajaran Gambar Seri adalah segala sesuatu yang dapat digunakan untuk menyalurkan pesan (bahan pembelajaran), yang berupa tiruan tiruan benda, orang atau pandangan yang dihasilkan pada permukaan yang rata dengan adanya rangkaian yang berturut-turut baik itu cerita, buku, peristiwa, dan sebagainya.

Gambar seri merupakan serangkaian gambar yang terpisah antara satu dengan yang lain tetapi memiliki satu-kesatuan urutan cerita. Gambar seri akan sulit dipahami ketika berdiri sendiri-sendiri dan belum diurutkan. Gambar seri akan memiliki makna setelah diurutkan berdasarkan pola-pola tertentu atau sesuai dengan urutan sebuah cerita. Gambar seri digunakan sebagai media dalam pembelajaran kemampuan menulis cerita/karangan.

Penggunaan media gambar berseri untuk pengajaran menulis cerita. Dianggap tepat dan mampu meningkatkan kemampuan menulis narasi. Selain itu, biaya yang dikeluarkan untuk memperoleh media ini tidak besar sehingga gambar-gambar yang diberikan pada siswa dapat bervariasi. Dengan adanya variasi gambar, siswa tidak akan jenuh. Alasan lain yang penggunaan media ini adalah dengan ditampilkannya 
gambar berseri, siswa akan belajar berpikir logis mengenai hubungan sebab akibat, kaitan antara satu kegiatan dengan kegiatan yang lain yang mengikutinya. Berdasarkan uraian di atas maka peneliti merasa terpanggil untuk melakukan penelitian eksperimen menggunakan media gambar seri.

Berdasarkan uraian di atas rumusan masalah dalam penelitian ini adalah: "Apakah penggunaan media gambar seri efektif terhadap pembelajaran keterampilan menulis cerita siswa dalam mata pelajaran Bahasa Indonesia pada Kelas III SD Negeri 10 Parenring Kecamatan Tanete Riaja Kabupaten Barru?". Penelitian ini bertujuan untuk mendekskripsikan penggunaan media gambar seri dalam pembelajaran terhadap peningkatan keterampilan menulis cerita Kelas III SD Negeri 10 Parenring Kecamatan Tanete Riaja Kabupaten Barru.

\section{Pengertian Menulis dalam Bahasa Indonesia}

Menulis merupakan kegiatan yang paling sering dilakukan oleh setiap orang. Menulis membutuhkan keterampilan khusus yang harus dipelajari dan senantiasa dilatih. Menulis memerlukan keterampilan tambahan bahkan motivasi tambahan pula, hal ini dikarenakan menulis bukan bakat karena tidak semua orang mampu untuk menulis. Susanto (2013: 246)

Menurut Tarigan (2008:21) menulis ialah menurunkan atau melukiskan lambang-lambang grafik yang menggambarkan suatu bahasa yang dipahami oleh seseorang sehingga orang lain dapat membaca lambang-lambang grafik tersebut kalau mereka memahami bahasa dan dan gambaran grafik itu.

Pembelajaran menulis di SD guru tidak seharusnya hanya berorientasi pada hasil tetapi harus berorientasi pada proses yang dilakukan. Keterampilan menulis merupakan keterampilan yang sangat kompleks dibanding dengan keterampilan lainnya. Karena didalam keterampilan menulis diperlukan pemahaman tentang konsep yang akan di bahas, pemahaman mengenai apa yang di bahas, penyusunan kalimat yang jelas serta penggunaan tanda baca yang benar. Selain itu harus ada perbedaan yang mendasar antara bahasa tulis dan bahasa lisan.

\section{Pengertian Media Gambar Seri (Media Visual)}

Kata media berasal dari bahasa latin yaitu medius yang secara harfiah yang berarti tengah, perantara, atau pengantar. Menurut Oemar Hamalik (1986:43) berpendapat bahwa "Gambar adalah segala sesuatu yang diwujudkan secara visual 
dalam bentuk dua dimensi sebagai curahan perasaan atau pikiran". Sedangkan dalam Kamus Besar Bahasa Indonesia (2001: 329) “Gambar adalah tiruan barang, binatang, tumbuhan dan sebagainya".

Media gambar merupakan salah satu bentuk media ajar yang termasuk jenis media visual yang diketahui memberi pengaruh paling besar terhadap siswa di antara jenis media lainnya.

Winataputra (2005:55) menyatakan bahwa penglihatan (visual) memiliki komposisi paling besar (75\%) dalam hal rata-rata jumlah informasi yang dapat diperoleh seseorang. Informasi yang diperoleh melalui penglihatan juga lebih mudah ditangkap dan diingat oleh memori seseorang.

Jadi dapat disimpulkan bahwa Media pembelajaran Gambar Seri adalah segala sesuatu yang dapat digunakan untuk menyalurkan pesan (bahan pembelajaran), yang berupa tiruan-tiruan benda, orang atau pandangan yang dihasilkan pada permukaan yang rata dengan adanya rangkaian yang berturut-turut baik itu cerita, buku, peristiwa, dan sebagainya.

\section{METODE PENELITIAN}

Jenis penelitian yang dilakukan dalam penelitian ini adalah penelitian pra-eksperimen atau pre-experimental. Rancangan yang digunakan adalah "One Group Pretest-Posttest Design". Pembelajaran diukur sebelum dan sesudah pemberian perlakuan.

Populasi penelitian ini adalah seluruh siswa SDN 10 Parenring Kecamatan Tanete Riaja Kabupaten Barru, dengan jumlah 159 orang. Pada penelitian ini, peneliti menggunakan kelas III SD Negeri 10 Parenring Kecamatan Tanete Riaja Kabupaten Barru dengan jumlah siswa 30 orang yang yang terdiri dari 12 murid laki- laki dan 18 murid perempuan. Instrument yang di gunakan dalam penelitian ini untuk mengukur keterampilan menulis cerita siswa adalah pemberian tugas menulis cerita yang diberikan sebelum dan sesudah penerapan tindakan (Treatment. Dalam penelitian ini, data yang terkumpul akan dianalisis dengan menggunakan teknik statistik deskriptif.

\section{HASIL PENELITIAN DAN PEMBAHASAN}

Hasil dan analisis data penelitian dibuat berdasarkan data yang diperoleh dari kegiatan penelitian tentang hasil belajar siswa melalui penggunaan media gambar seri 
yang telah dilaksanakan di SDN 10 Parenring Kecamatan Tanete Riaja Kabupaten Barru. Penelitian ini dilaksanakan selama lima kali pertemuan, dimana pertemuan pertama diberikan pretest untuk mengetahui kemampuan awal siswa dan diberikan posttest setelah perlakuan.

a. Tingkat Hasil Belajar Bahasa Indonesia Siswa Sebelum Diberikan Perlakuan (Treatment) atau Pretest

Untuk memberikan gambaran awal tentang hasil belajar Bahasa Indonesia siswa pada kelas III yang dipilih sebagai unit penelitian. Berikut disajikan skor hasil belajar siswa kelas III sebelum diberikan perlakuan.

Tabel 1. Deskripsi Skor Hasil Belajar Bahasa Indonesia Siswa Kelas III sebelum diberikan Perlakuan (Treatment) atau Pretest

\begin{tabular}{|c|c|}
\hline Statistik & Nilai Statistik \\
\hline Ukuran Sampel & 30 \\
Skor Tertinggi & 79 \\
Skor Terendah & 31 \\
Skor Ideal & 100 \\
Rentang Skor & 48 \\
Skor Rata-Rata & 58.73 \\
Standar Deviasi & 13.970 \\
\hline
\end{tabular}

Berdasarkan Tabel 1 menunjukkan bahwa rata-rata skor hasil belajar Bahasa Indonesia pada pokok bahasan menulis ceritasebelum dilakukan perlakuan (Pretest) adalah 58,73 dari skor ideal 100. Skor tertinggi yang dicapai siswa adalah 79 dan skor terendah 31, dengan standar deviasi sebesar 13.970 yang berarti bahwa skor hasil belajar Bahasa Indonesia siswa pada Pretestdi SDN 10 Parenring Kecamatan Tanete Riaja Kabupaten Barru tersebar dari skor terendah 31 sampai skor tertinggi 79

Jika skor tes hasil belajar Bahasa Indonesia siswa sebelum perlakuan (Pretest) dikelompokkan ke dalam lima kategori, maka diperoleh distribusi skor frekuensi dan persentase yang ditunjukkan pada Tabel 5. berikut:

Tabel 2 Distribusi dan Persentase Skor Hasil Belajar Bahasa Indonesia Siswa Kelas III sebelum diberikan Perlakuan ( Treatment) atau Pretest

\begin{tabular}{|c|c|c|c|c|}
\hline No. & Skor & Kategori & Frekuensi & $\begin{array}{c}\text { Persentase } \\
\text { (\%) }\end{array}$ \\
\hline
\end{tabular}




\begin{tabular}{|l|c|c|c|c|}
\hline 1. & $0-55$ & Sangat Rendah & 11 & 36,67 \\
2. & $56-74$ & Rendah & 12 & 40 \\
3. & $75-84$ & Tinggi & 7 & 23,33 \\
4. & $85-100$ & Sangat Tinggi & 0 & 0 \\
\hline \multicolumn{2}{|l}{ Jumlah } & $\mathbf{3 0}$ & $\mathbf{1 0 0}$ \\
\hline
\end{tabular}

Berdasarkan Tabel 1 dan Tabel 2 dapat digambarkan bahwa dari 30 siswa kelas III SDN 10 Parenring Kecamatan Tanete Riaja Kabupaten Barruyang hasil Pretest, pada umumnya memiliki tingkat hasil belajar Bahasa Indonesia dalam kategori rendah dengan skor rata - rata 58,73 dari skor ideal 100.

Kemudian untuk melihat persentase ketuntasan belajar Bahasa Indonesia siswa sebelum perlakuan (Pretest) dapat dilihat pada Tabel 6. berikut :

Tabel 3 Deskripsi Ketuntasan Belajar Bahasa Indonesia Siswa Kelas III SDN 10 Parenring Kecamatan Tanete Riaja Kabupaten Barru pada Pretest

\begin{tabular}{|c|c|c|c|}
\hline Skor & Kategorisasi & Frekuensi & $\begin{array}{c}\text { Persentase } \\
\text { (\%) }\end{array}$ \\
\hline $75-100$ & Tuntas & 7 & 23,33 \\
\hline $0-74$ & Tidak Tuntas & 23 & 76,67 \\
\hline \multicolumn{2}{|c|}{ Jumlah } & $\mathbf{3 0}$ & $\mathbf{1 0 0}$ \\
\hline
\end{tabular}

Berdasarkan Tabel 3. sebelum perlakuan (Pretest) dapat digambarkan bahwa yang telah mencapai ketuntasan belajar sebanyak 7 orang dari jumlah keseluruhan 30 orang dengan persentase 23,33\%, sedangkan yang tidak mencapai ketuntasan belajar sebanyak 23 orang dari jumlah keseluruhan 30 siswa dengan persentase 76,67\%.

b. Tingkat Hasil Belajar Bahasa Indonesia Siswa Setelah Diberikan Perlakuan (Treatment) atau Posttest.

Berikut disajikan deskripsi dan persentase hasil belajar Bahasa Indonesia siswa Kelas III setelah diberikan perlakuan atau posttest.

Tabel 4. Deskripsi Skor Hasil Belajar Bahasa Indonesia Siswa Kelas III setelah diberikan Perlakuan(Treatment) atau Posstest 


\begin{tabular}{|c|c|}
\hline Statistik & Nilai Statistik \\
\hline Ukuran Sampel & 30 \\
Skor Tertinggi & 90 \\
Skor Terendah & 60 \\
Skor Ideal & 100 \\
Rentang Skor & 30 \\
Skor Rata-Rata & 76,13 \\
Standar Deviasi & 7,825 \\
\hline
\end{tabular}

Berdasarkan Tabel 4. menunjukkan bahwa rata-rata skor hasil belajar Bahasa Indonesia pada pokok bahasan menulis ceritayang diajarkan dengan menggunakan media gambar seri adalah 76,13 dari skor ideal 100. Skor tertinggi yang dicapai siswa adalah 90 dan skor terendah 30, dengan standar deviasi sebesar 7,825 yang berarti bahwa skor hasil belajar Bahasa Indonesiasiswa pada Posttest kelas III SDN 10 Parenring Kecamatan Tanete Riaja Kabupaten Barrutersebar dari skor terendah 60 sampai skor tertinggi 90.

Jika skor tes hasil belajar Bahasa Indonesia siswa yang diajar dikelompokkan kedalam lima kategori, maka diperoleh distribusi skor frekuensi dan persentase yang ditunjukkan pada Tabel 8. berikut:

Tabel 5. Distribusi dan Persentase Skor Hasil Belajar Bahasa Indonesia Siswa Kelas III setelah diberikan Perlakuan (Treatment) atau

Posstest

\begin{tabular}{|c|c|c|c|c|}
\hline No. & Skor & Kategori & Frekuensi & $\begin{array}{c}\text { Persentase } \\
\text { (\%) }\end{array}$ \\
\hline 1 & $0-55$ & Sangat Rendah & 0 & 0 \\
2 & $56-74$ & Rendah & 12 & 40 \\
3 & $75-84$ & Tinggi & 12 & 40 \\
4 & $85-100$ & Sangat Tinggi & 6 & 20 \\
\hline \multicolumn{2}{|c|}{ Jumlah } & $\mathbf{3 0}$ & $\mathbf{1 0 0}$ \\
\hline
\end{tabular}

Berdasarkan tabel 4. dan 5. di atas, dapat digambarkan bahwa dari 30 siswa kelas III SDN 10 Parenring Kecamatan Tanete Riaja Kabupaten Barruyang 
dijadikan sampel penelitian Posttest, pada umumnya memiliki tingkat hasil belajar Bahasa Indonesia dalam kategori tinggi dengan skor rata-rata 76,13 dari skor ideal 100.

Kemudian untuk melihat persentase ketuntasan belajar Bahasa Indonesia siswa setelah perlakuan (Posttest) dengan menerapkan media gambar seri dapat dilihat pada Tabel 8. berikut :

Tabel 6. Deskripsi Ketuntasan Belajar Bahasa Indonesia Siswa Kelas

III setelah diberikan Perlakuan (Treatment) atau Posstest

\begin{tabular}{|c|c|c|c|}
\hline Skor & Kategorisasi & Frekuensi & Persentase (\%) \\
\hline $65-100$ & Tuntas & 18 & 60 \\
\hline $0-64$ & Tidak Tuntas & 12 & 40 \\
\hline \multicolumn{2}{|c|}{ Jumlah } & $\mathbf{3 0}$ & $\mathbf{1 0 0}$ \\
\hline
\end{tabular}

Berdasarkan Tabel 6. setelah perlakuan (Posttest) dengan menerapkan media gambar seri dapat digambarkan bahwa yang telah mencapai ketuntasan belajar sebanyak 18 orang dari jumlah keseluruhan 30 orang dengan persentase $60 \%$, sedangkan yang tidak mencapai ketuntasan belajar sebanyak 12 orang dari jumlah keseluruhan 30 siswa dengan persentase 40\%.Apabila tabel 8. dikaitkan dengan indikator ketuntasan hasil belajar siswa maka dapat disimpulkan bahwa hasil belajar Bahasa Indonesia siswa kelas III SDN 10 Parenring Kecamatan Tanete Riaja Kabupaten Barru setelah menerapkan media gambar seri sudah memenuhi indikator ketuntasan hasil belajar secara klasikal.

\section{c. Perbandingan Tingkat Hasil Belajar Siswa Antara Pretest dan Posttest}

Dari pembahasan di atas, apabila disajikan dalam tabel akan terlihat jelas perbedaaan hasil belajar siswa sebelum dilaksanakan perlakuan (Pretest) dan setelah dilaksanakan perlakuan (Posttest), yang ditunjukkan Tabel 9. berikut ini:

Tabel 7. Distribusi Hasil Belajar Bahasa Indonesia Siswa Hasil Pretest dan Posttest

\begin{tabular}{|c|c|c|}
\hline \multirow{2}{*}{ Statistik } & \multicolumn{2}{|c|}{ Nilai Statistik } \\
\cline { 2 - 3 } & Pretest & Posttest \\
\hline Ukuran Sampel & 30 & 30 \\
Skor Tertinggi & 79 & 90 \\
\hline
\end{tabular}




\begin{tabular}{|c|c|c|}
\hline \multirow{2}{*}{ Statistik } & \multicolumn{2}{|c|}{ Nilai Statistik } \\
\cline { 2 - 3 } & Pretest & Posttest \\
\hline Skor Terendah & 31 & 60 \\
Skor Ideal & 100 & 100 \\
Rentang Skor & 48 & 30 \\
Skor Rata-Rata & 58,73 & 76,13 \\
Standar Deviasi & 13.970 & 7,825 \\
\hline
\end{tabular}

Dari Tabel 7. di atas digambarkan bahwa skor rata-rata siswa setelah dilaksanakan media gambar seri (Posttest) lebih tinggi yaitu 76,13 dengan rentang skor 30 dibanding dengan Pretest atau sebelum dilaksanakan perlakuan yaitu 58,73 dengan rentang skor 48. Dengan demikian menurut kriteria keefektifan pada Bab III, hasil belajar siswa meningkat setelah diberikan perlakuan dengan menggunakan media gambar seri.

Berdasarkan nilai yang diuraikan, terlihat bahwa jumlah nilai dari posttest(setelah perlakuan) lebih tinggi dibandingkan pretest (sebelum perlakuan) yang diperoleh murid kelas III SDN 10 Parenring Kecamatan Tanete Riaja Kabupaten Barru.Hal ini dapat dilihat pada persentase rata-rata nilai yang diperoleh oleh siswa kelas III setelah perlakuan (posttest) lebih tinggi yakni mencapai 60\%.Sedangkan persentase rata-rata nilai yang diperoleh siswa sebelum perlakuan (pretest) terlihat lebih rendah yakni hanya mencapai 40\%. Dengan demikian media gambar seri efektif diterapkan untuk meningkatkan keterampilan menulis cerita.

Kemampuan menulis di SD tidak diperoleh dari hasil begitu saja akan tetapi memerlukan tahap - tahap pembelajaran yang membutuhkan waktu yang tidak sedikit tetapi membutuhkan proses yang cukup lama. Proses yang dilakukan oleh siswa dalam melatih menulis dipermulaan yang secara formal dilakukan melalui pembelajararan bahasa Indonesia yang dimulai sejak SD.

Banyak guru Sekolah Dasar mengalami kesulitan untuk membiasakan anak belajar menulis.Penyebabnya adalah kesalahan dalam hal pengajaran yang terlalu kaku sehingga menimbulkan kesan bahwa menulis itu sulit.Selain itu guru SD banyak pula yang belum memahami pentingnya keterampilan menulis. 
Salah satu upaya yang bisa dilakukan oleh seorang guru dalam proses pembelajaran agar siswa lebih aktif dan kreatif dalam pembelajaran bahasa Indonesia khususnyaketerampilan menulis cerita di kelas III yaitu dengan menggunakan media gambar seri dalam pembelajaran bahasa Indonesia. Media pembelajaran gambar seri adalah segala sesuatu yang dapat digunakan untuk menyalurkan pesan (bahan pembelajaran), yang berupa tiruan tiruan benda, orang atau pandangan yang dihasilkan pada permukaan yang rata dengan adanya rangkaian yang berturut-turut baik itu cerita, buku, peristiwa, dan sebagainya. Untuk itu peneliti melakukan penelitian dengan menerapkan media gambar seri untuk melihat pengaruh keterampilan menulis cerita siswa di kelas III SDN 10 Parenring.

Penelitian ini merupakan penelitian eksperimen yang hanya melibatkan satu sampel yang kemudian diberi perlakuan berupa pembelajaran media gambar seri.Dalam pelaksanaannya, pengumpulan data dilakukan dengan lembar observasi dan melalui tes. Lembar observasi dimaksudkan untuk mengamati seluruh aktifitas siswa selama proses belajar mengajar berlangsung sedangkan dalam pengumpulan data dengan tes dimaksudkan untuk mengukur tingkat penguasaan menulis siswa. Dalam pemberian tes dilakukan dengan pretest dan posttest, pretest dimaksudkan untuk mengukur tingkat penguasaan menulis ceritasiswa sebelum diterapkannya pembelajaran melalui media gambar seri dengan asumsi bahwa siswa masih menerapkan model pembelajaran yang diberikan oleh guru membaca menulis ceritanya sedangkan posttest dimaksudkan untuk mengukur penguasaan menulis cerita siswa setelah diberi perlakuan melalui media gambar seri.

Berdasarkan analisis data deskriptif hasil belajar siswa sebelum diterapkan pembelajaran menulis cerita dengan menggunakan media gambar seri menunjukkan bahwa terdapat 23 siswa dari jumlah keseluruhan 30 siswa atau 76,67 \% siswa yang tidak mencapai ketuntasan, dengan kata lain hasil belajar siswa sebelum diterapkan media gambar seri rendah dan tidak memenuhi kriteria ketuntasan klasikal.

Hasil belajar siswa setelah diterapkan media gambar seri.Hasil analisis data hasil belajar siswa setelah diterapkan pembelajaran menulis cerita dengan menggunakan media gambar seri menunjukkan bahwa terdapat 18 siswa atau $60 \%$ siswa mencapai ketuntasan individu (skor minimal 75) sedangkan siswa yang tidak 
mencapai ketuntasan minimal atau individu sebanyak 12 atau $40 \%$. Hal ini berarti bahwa media gambar seri dapat membantu siswa untuk mencapai ketuntasan klasikal.

Pengaruh Hasil belajar siswa setelah pembelajaran. Hasil analisis data hasil belajar siswa setelah diterapkan pembelajaran Bahasa Indonesia melalui media gambar seri menunjukkan bahwa skor rata - rata siswa setelah diterapkan media gambar seri (Posttest) mengalami pengaruh yang signifikan atau lebih tinggi yaitu 76,13 dengan rentang skor 30 dibanding dengan Pretest atau sebelum dilaksanakan perlakuan yaitu 58,73 dengan rentang skor 48 .

Hasil pengamatan aktivitas siswa dalam pembelajaran menulis cerita dengan menggunakan media gambar seri pada siswa kelas III SDN 10 Parenring Kecamatan Tanete Riaja Kabupaten Barru menunjukkan bahwa belum memenuhi kriteria aktif karena sesuai dengan indikator aktivitas siswa bahwa aktivitas siswa dikatakan berhasil/efektif jika sekurang-kurangnya 75\% siswa terlibat aktif dalam proses pembelajaran. Sedangkan hasil analisis data observasi aktivitas siswa rata-rata persentase frekuensi aktivitas siswa dengan pembelajaran menulis cerita dengan menggunakan media gambar seri yaitu 68,42\% dari aktivitas siswa setiap pertemuan.

Hal ini dapat disimpulkan bahwa siswa belum aktif mengikuti proses pembelajaran Bahasa Indonesia melalui penerapan media gambar seri.

Hasil analisis respon siswa pada penerapan media gambar seri yaitu siswa yang senang menulis sebesar $66,67 \%$, siswa yang merasa terbantu dengan adanya media gambar seri sebesar 93,33\%, siswa yang setuju jika pembelajaran berikutnya guru menerapkan media gambar sebesar 90\%, siswa yang merasa ada kemajuan setelah pembelajaran dengan media gambar seri sebesar 83,33\%, siswa yang senang menulis cerita dengan menerapkan media gambar seri sebesar $80 \%$ dan siswa yang suka dengan cara guru mengajar sebesar $76,67 \%$.

Hal ini dapat disimpulkan bahwa siswa dapat lebih aktif memberikan respon pembelajaran Bahasa Indonesia melalui penerapan media gambar seri dan dengan demikian media gambar seri efektif diterapkan untuk pembelajaran keterampilan menulis cerita.

\section{SIMPULAN DAN SARAN}


Hasil belajar menulis cerita siswa kelas III SDN 10 Parenring Kecamatan Tanete Riaja Kabupaten Barru sebelum diajar dengan menggunakan media gambar seri menunjukkan bahwa skor rata-ratanya adalah 58,73 dari skor ideal 100 dengan standar deviasi 13,970 dan berada pada kategori "sangat rendah". Hasil belajar menulis cerita siswa kelas III SDN 10 Parenring Kecamatan Tanete Riaja Kabupaten Barru, setelah diajar dengan menggunakan media gambar seri menunjukkan bahwa skor rata-ratanya adalah 76,13 dari skor ideal 100 dengan standar deviasi 7,825 dan berada pada kategori "tinggi”.

Dari persentase sebesar $67,50 \%$ menunjukkan bahwa rata-rata siswa yang aktif dalam pembelajaran menulis cerita melalui media gambar seri lebih efektif diterapkan pada siswa kelas III SDN 10 Parenring Kecamatan Tanete Riaja Kabupaten Barru.

Dari persentase sebesar $81,67 \%$ menunjukkan bahwa rata-rata siswa yang memberi respon positif terhadap pembelajaran membaca permulaan melalui media kartu kata lebih efektif diterapkan pada siswa kelas III SDN 10 Parenring Kecamatan Tanete Riaja Kabupaten Barru. Ini berarti bahwa penggunaan media gambar seri efektif terhadap pembelajaran keterampilan menulis cerita siswa kelas III SDN 10 Parenring Kecamatan Tanete Riaja Kabupaten Barru.

Saran yang dapat diberikan Pembelajaran media gambar seri perlu dilaksanakan oleh guru. Karenamelalui pembelajaran media gambar seri siswa terlatih untuk mengidentifikasi, menganalisis dan mengevaluasi permasalahan dengan cermat sehingga siswa dapat mengembangkan daya nalarnya untuk menyelesaikan masalah yang dihadapi. Perlu adanya penelitian lebih lanjut mengenai pembelajaran dengan menggunakan media gambar seri dalam pembelajaran keterampilan menulis cerita pada tingkatan SD.

\section{DAFTAR PUSTAKA}

Arikunto, Suhardjono dan Supardi. 2009. Penelitian Tindakan Kelas. Jakarta: Bumi Aksara

Djamarah, Syaiful Bahri dan Aswan Zain. 2006. Strategi Belajar Mengajar. Jakarta: Rineka Cipta 
Depdiknas. 2006. Kurikulum Tingkat Satuan Pendidikan Pengajaran Bahasa Indonesia Sekolah Dasar. Jakarta: Depdiknas

Depdiknas. 2003. Undang-undang SISDIKNAS. Jakarta

Hamalik, Oemar. 1986. Psikologi Belajar Mengajar. Bandung: Sinar baru

Khusnul, Khotimah. 2008. Hakikat Pendidikan. Jakarta: Erlangga

Latuheru, John D. 2003. Media Pengajaran. Jakarta: Direktorat Jenderal Pendidikan Tinggi

Qodir, Abdullah. 2008. Pengertian Media Gambar Seri, (online)

(http://repository.uksw.edu//bitstream/handle/123456789/2013/T1 2620107

85 Bab\%20II.pdf?sequence $=3$, diakses pada tanggal 04 maret 2016)

Rusyana, Yus. 1984. Metode Pengajaran Sastra. Yogyakarta: Kanisius

Sabarti, Akhadiah. 1993. Bahasa Indonesia 1. Jakarta: Departemen Pendidikan dan Kebudayaan

Sadiman, Arief. 2003. Media Pendidikan. Jakarta: Rajawali Press

Stewig, Sabesta. Dkk. 1999. Belajar dan Pembelajaran Menulis Bahasa Indonesia. Jakarta: Erlangga

Sudjana, Dkk. 1990. Media Pengajaran. Bandung: Sinar Baru

Sugiyono. 2014. Metode Penelitian Pendidikan (Pendekatan Kuantitatif, Kualitatif dan $R \&)$. Bandung: Alfabeta

Sulaiman. 1998. Media Pendidikan. Jakarta: CV Rajawali

Suparno dan Yunus Mohammad. 2008. Keterampilan Dasar Menulis. Jakarta: Universitas Terbuka

Susanto. 2013. Teori Belajar dan Pembelajaran di Sekolah Dasar. Jakarta: Prenada Media Group

Syafi'Ie, Iman. 1999. Pengajaran Membaca dan Menulis di Kelas Awal Sekolah Dasar. Malang: Departemen Pendidikan dan Kebudayaan

Syamsuri, Sukri, dkk. 2014. Pedoman Penulisan Skripsi. Makassar: Panrita Press Unismuh Makassar 
Tarigan, Djago dan Henry Guntur. Tarigan. 1986. Teknik Pengajaran Keterampilan Berbahasa. Bandung: Angkasa

Tarigan Henry Guntur. 1982. Menulis Sebagai Keterampilan Berbahasa. Bandung: Angkasa

Winataputra. 2005. Strategi Belajar Mengajar. Jakarta: Universitas Terbuka 